\title{
A diabetes és a depresszió együttes előfordulása, lehetséges kétirányú kapcsolata és szürésük jelentősége
}

\author{
Hargittay Csenge dr. ${ }^{1}$. Márkus Bernadett dr. ${ }^{1}$ \\ Vörös Krisztián dr. ${ }^{1}$ - Tabák Gy. Ádám dr. ${ }^{2}$ \\ 'Semmelweis Egyetem, Általános Orvostudományi Kar, Családorvosi Tanszék, Budapest \\ ${ }^{2}$ Semmelweis Egyetem, Általános Orvostudományi Kar, I. Belgyógyászati Klinika, Budapest
}

\begin{abstract}
A cukorbetegség és a depresszió világszerte népbetegség. Mindkettő kialakulása multifaktoriális, amelyben szerepet játszhatnak külső, környezeti tényezők, valamint belső, a szervezetben játszódó folyamatok, többek között különböző gének nem megfelelő múködése. Bár a diabetes és a depresszió komorbiditása jól ismert, a két betegség hátterében zajló folyamatok, illetve ezen folyamatok egymásra hatása nem minden részletet illetóen tisztázott. A szerzők összefoglaló közleményének célja bemutatni a 2-es típusú cukorbetegség és a depresszió közötti kétirányú kapcsolat hátterében álló ismert és még csak feltételezett mechanizmusokat, illetve felhívni a figyelmet a két betegség egyidejü szűrésének és kezelésének fontosságára, hiszen együttes fennállásukkor nőhet a morbiditás és a mortalitás. A cukorbetegek depresszióra irányuló szúrésével és a depressziós betegek diabetes irányú kivizsgálásával csökkenthető lehet a komorbiditásból származó komplikációk és szövődmények, illetve a kezelési nehézségek előfordulása. A két betegség ellátásában fontos szerepe van a családorvosnak, aki a korai diagnózissal és kezeléssel javíthatja a betegek életminőségét, lassíthatja a betegségek progresszióját és a szövődmények kialakulásának kockázatát.
\end{abstract}

Orv Hetil. 2019; 160(21): 807-814.

Kulcsszavak: 2-es típusú diabetes, depresszió, komorbiditás

\section{Co-occurrence of diabetes and depression, their potential bidirectional association and the significance of their screening}

Diabetes and depression are considered global epidemics. Both have multifactorial aetiologies, including external, environmental factors and internal factors in connection with physiological processes as well as genetic variants triggering disease onset. Although the co-occurrence of diabetes and depression is well described, the mechanisms underlying these diseases and their interactions are still not entirely revealed. The authors aimed to present known and potential explanations of the co-occurrence of these diseases and to highlight the importance of their timely diagnosis and effective treatment, as their co-occurrence may increase morbidity and mortality. Screening for depression among diabetes patients and for diabetes among patients with depression may decrease the incidence of complications and consequences of this comorbidity and may foster more effective treatment. General practitioners play a key role in the care of both diseases by providing timely diagnosis and adequate treatment potentially leading to a better quality of life, slower disease progression and decreased risk of complications.

Keywords: type 2 diabetes mellitus, depression, comorbidity

Hargittay Cs, Márkus B, Vörös K, Tabák GyÁ. [Co-occurrence of diabetes and depression, their potential bidirectional association and the significance of their screening]. Orv Hetil. 2019; 160(21): 807-814.

(Beérkezett: 2018. december 29.; elfogadva: 2019. január 28.) 


\section{Rövidítések}

$\mathrm{CI}=$ (confidence interval) megbízhatósági intervallum; DSM $=($ Diagnostic and statistical manual of mental disorders $)$ Mentális rendellenességek kórmeghatározó és statisztikai kézikönyve; $\mathrm{EU}=$ (European Union) Európai Unió; FINDRISC = (Finnish Diabetes Risk Score) finn diabetesrizikó-pontszám; HADS $=$ (Hospital Anxiety and Depression Scale) Kórházi Szorongás és Depresszió Skála; $\mathrm{HbA}_{\mathrm{lc}}=$ hemoglobin $\mathrm{A}_{\mathrm{lc}}$; $\mathrm{HR}=($ hazard ratio $)$ kockázati arány; IDF $=($ International Diabetes Federation) Nemzetközi Diabetes Szövetség; IGFI = (insulin-like growth factor-I) inzulinszerű növekedési faktor-I; OGTT $=($ oral glucose tolerance test $)$ orális glükóztoleranciateszt; $\mathrm{OR}=($ odds ratio $)$ esélyhányados; $\mathrm{P} 2 \mathrm{RX} 7=($ purinergic receptor $\mathrm{P} 2 \mathrm{X}$, ligand-gated ion channel, 7) purinerg ioncsatornagén; $\mathrm{RR}=($ relative risk $)$ relatív rizikó; $\mathrm{TPH} 2$ = triptofánhidroxiláz-2; $\mathrm{TNF} \alpha=$ (tumor necrosis factor alpha) tumornekrózisfaktor-alfa; WHO = (World Health Organization) Egészségügyi Világszervezet

A cukorbetegség a gyakorisága és szövődményei révén korunk egyik legjelentősebb népbetegsége, óriási betegségterhet jelent. A cukorbetegségben szenvedők száma évról évre emelkedik, a Nemzetközi Diabetes Szövetség (International Diabetes Federation, IDF) becslése szerint jelenleg minden 11 . felnőtt diabeteses (425 millió), ami 2045-re előreláthatóan 629 millióra növekszik. Szintén az IDF becslése szerint Magyarországon 2017 ben a cukorbetegség prevalenciája $7,5 \%$ volt a 20 és 79 év közötti korosztályban [1].

Magyarországon a Jermendy és mtsai által 2005-ben végzett keresztmetszeti vizsgálat eredményei alapján a 20-69 éves populációban a diabetes előfordulása (családorvos által regisztrált és éhomi vércukor alapján frissen diagnosztizált diabetes) $8,65 \%$ volt (férfiak: $11,16 \%$; nők: 6,41\%). Életkorra és nemre való súlyozás után a teljes 20-69 éves populációra vetítve ez 7,5\%-os előfordulást jelent [2].

A korábbi Országos Egészségbiztosítási Pénztár (jelenleg Nemzeti Egészségbiztosítási Alapkezelő) adatbázisának 2014-ben történt elemzése alapján 727000 fó használt valamilyen antidiabetikumot 2 -es típusú cukorbetegség miatt, ami a teljes lakosságra vonatkoztatott $7,3 \%$-os előfordulást jelent. 2001 és 2014 között a korra és nemre standardizált prevalencia 4,2\%-ról 6,4\%-ra nőtt. Az életkor előrehaladtával nótt az előfordulási gyakoriság, 2011-ben a 61-70 év közöttiek körében 19,0\%, a 70 év felettiek között pedig 20,0\% volt [3]. Az Egészségügyi Világszervezet (World Health Organization, WHO) új Globális Diabetes Jelentésében (Global Report on Diabetes) közzétett országprofilja szerint diabetes a halál direkt oka az esetek $2 \%$-ában, és diabetesszel összefüggő az esetek kb. 6\%-a [4].

A felnőtt magyar lakosság körében 2002-ben önértékeléssel történt országos reprezentatív felmérés (Hungarostudy) alapján a diabetes előfordulási gyakorisága 6,2\% $(95 \%$ CI 5,7-6,6) volt [5]. A gyakorlatilag azonos metodikával végzett, 10 évvel későbbi vizsgálat jelentős, 89\%- os (OR 1,89; CI 1,53-2,32) emelkedést írt le a cukorbetegség előfordulási gyakoriságában. A 2-es típusú diabetes mellitus életkorra standardizált prevalenciája $11,7 \%$ (95\% CI 10,0-13,8) volt. A legkifejezettebb növekedés az 55-64 éves korosztályban volt tapasztalható (11,6\%-ról 24,4\%-ra) [6].

A diabeteshez hasonlóan a depresszió is népbetegség. Becslések szerint 322 millió embert érint világszerte [7]. A Világ Mentális Egészsége (World Mental Health) címú jelentésben 2012-ben, 17 országban végzett felmérés alapján, minden 20. embernek volt az előző évben depressziós epizódja. A WHO előrejelzése szerint 2020-ra a depresszió lesz a munkaképesség-csökkenés második leggyakoribb oka, 2030-ra pedig várhatóan a betegségteher legnagyobb részét képezi majd [8]. Hazai, reprezentatív mintán végzett vizsgálatok szerint az unipoláris major depresszió élettartami és l éves aktuális (pont-) prevalenciája a felnőtt populációban $15,7 \%$ és 2,6\% [9].

$\mathrm{Az}$ alapellátásban ennél magasabb előfordulásokat találtak: az összes DSM-IV szerint depresszív kórképnek minősülő hangulatzavarok aktuális pontprevalenciája $18,5 \%$, ezen belül a major depressziós epizódé $7,3 \%$ volt [10].

A major depresszió szưrése és kezelése az alapellátásban segítheti az öngyilkossági kísérletek és a befejezett öngyilkosságok számának csökkenését [11-14]. A WHO becslése alapján 2015-ben 788000 ember halt meg öngyilkosság következtében, és ennél lényegesen több volt az öngyilkossági kísérletek száma [7]. Az Eurostat 2015ös adatai alapján Európában Litvániában volt a legmagasabb a százezer lakosra eső éves öngyilkossággal összefüggő halálozási arány $(30 / 100000$ versus $11 / 100000$ az EU-28-ban), míg Magyarország a negyedik helyen állt $(19 / 100000)$ [15].

A depresszió és a cukorbetegség egyaránt krónikus betegség, amelyek külön-külön is jelentős betegségterhet képviselnek. Együttes előfordulásukkor azonban tovább nő a morbiditás és a mortalitás, valamint az ellátás költsége. Rendkívül fontos ezért a depresszió és a diabetes korai felismerése az életminőség javításáért, az öngyilkossági rizikó csökkentéséért és a diabeteses szövődmények megelőzéséért. A szürésben és a korai kezelésben a családorvosoknak kiemelkedő szerepük van, hiszen a praxisokban történik a legtöbb orvos-beteg találkozás [16].

A jelen összefoglaló közlemény célja mindezek alapján bemutatni a 2 -es típusú cukorbetegség és a depresszió közötti kétirányú kapcsolat hátterében álló ismert és még csak feltételezett mechanizmusokat, illetve felhívni a figyelmet a két együttes betegség egyidejü szürésének és kezelésének fontosságára.

\section{Módszer}

A keresést a Scopus, Web of Science és a PubMed adatbázisokban végeztük az alapítástól 2018. decemberig a következő kulcsszavak kombinációival: 'diabetes melli- 
tus' vagy 'type 2 diabetes'; 'depression' vagy 'depressive'; és 'bidirectional' vagy 'comorbidity' vagy 'association'. Elsősorban az utóbbi 5 év publikációira hivatkoztunk, de nem zártuk ki az ennél régebbi, gyakran citált, illetve nagy jelentőségű közleményeket sem. A keresést kiegészítettük magyar nyelvű szakfolyóiratcikkek és szakkönyvfejezetek áttekintésével. A hivatkozások számának lehetséges csökkentése céljából adott kérdés vizsgálatakor előnyben részesítettük a metaanalíziseket és a szisztematikus összefoglaló közleményeket. Amennyiben ezek nem álltak rendelkezésre, a kérdéstől függően randomizált kontrollált vizsgálatokat, kohorszvizsgálatokat és ritkán keresztmetszeti elemzéseket választottunk. A keresés során felismert közlemények hivatkozásait is áttekintettük további releváns irodalmak után kutatva.

\section{A diabetes és a depresszió kétirányú kapcsolata}

A diabetes és a depresszió közti kétirányú kapcsolatról számos tanulmány született. A XVII. században $d r$. Thomas Willis azt figyelte meg, hogy azoknál az egyéneknél, akiknek az életében sok a stressz és a szomorúság, gyakrabban alakul ki cukorbetegség [17].

Egy nemrég megjelent keresztmetszeti vizsgálatban a depresszió és a szorongás együttes előfordulását tanulmányozták 90686 résztvevő bevonásával, akiket három csoportra osztottak: diagnosztizált cukorbetegek; cukorbetegek, akik nem tudtak betegségükrôl; és olyan résztvevők, akiknek nincs cukorbetegségük. Eredményeik alapján a depresszió előfordulási gyakorisága magasabb volt a cukorbetegek között, tekintet nélkül arra, hogy diagnosztizált (OR 1,4; 95\% CI 1,1-1,8) volt a betegségük vagy sem (OR 1,8; 95\% CI 1,3-2,6). Ráadásul a két diabeteses csoport között nem volt különbség a depreszszió előfordulásában (OR 0,7; p = 0,17) [18].

Hasonló eredményre jutott két korábbi metaanalízis is, amelyekben keresztmetszeti vizsgálatok adatait dolgozták fel $(\mathrm{n}=21351$ és $\mathrm{n}=51331)$. Eredményeik szerint a depresszió elöfordulása a diabeteses csoportban másfél-kétszer gyakoribb volt a kor és nem szerint illesztett egészséges kontrollcsoporthoz képest (OR 2,0; 95\% CI 1,8-2,2, illetve OR 1,6; 95\% CI 1,2-2,0) [19, 20$].$ Míg a cukorbetegek 17,6\%-a bizonyult depressziósnak, a kontrollpopulációban ennek elófordulása $9,8 \%$ volt. Megjegyzendő ugyanakkor, hogy a diabetesesek között a depresszióra hajlamosító tényezók is gyakrabban fordultak elö [20].

Kivimäki és mtsai hosszmetszeti vizsgálata arra utal, hogy a depresszió a cukorbetegség diagnózisától függetlenül gyakrabban fordul elő a később cukorbetegséggel diagnosztizált személyekben, azaz nem a diabetes diagnózisa, a kezeléssel kapcsolatos tényezők növelik a depresszió kockázatát ezekben a személyekben. Kivimäki és mtsai az antidepresszívumok használatát követték 4 évvel a cukorbetegség diagnózisa előtt és 4 évvel utána, 493 résztvevőnél, akiknél 2-es típusú cukorbetegséget diagnosztizáltak, és 2450 nem cukorbeteg, korra, nemre és szociális helyzetre igazított kontrollszeméllyel. Eredményeik alapján az antidepresszívumok használata azoknál, akiknél később cukorbetegség alakult ki, kétszer gyakoribb volt a nem cukorbeteg kontrollcsoporthoz képest (OR 2,00; 95\% CI 1,57-2,55). A relatív különbség az antidepresszáns-használatban a két csoport között közel hasonló volt a cukorbetegség diagnózisa előtti és utáni években, kivéve a gyógyszer használatának átmeneti kiugró növekedését a cukorbetegség diagnózisának évében (OR 2,66; 95\% CI 1,94-3,65) [21].

Eredményeiket megerősíti az a metaanalízis is, amely 16 hosszmetszeti vizsgálat adatai alapján $(n=497223)$ cukorbetegek között magasabb depresszióincidenciát talált a nem cukorbetegekhez képest (1,6\% versus $1,4 \%$, nyers HR 1,29; 95\% CI 1,18-1,40 és igazított HR 1,25; 95\% CI 1,10-1,44) [22].

Eaton és mtsai prospektív vizsgálatukban a fordított irányú összefüggést elemezték, depressziós betegek között tanulmányozva a cukorbetegség kialakulását. Eredményeik szerint a major depresszió fennállása több mint kétszeresre növelte a későbbi 2-es típusú cukorbetegség kockázatát (RR 2,23; 95\% CI 0,90-5,55) [23].

Mezuk és mtsai prospektív vizsgálatok metaanalízise kapcsán egyszerre vizsgálta mindkét irányban a kapcsolatot. Depresszió fennállása esetén a 2-es típusú cukorbetegség 60\%-kal magasabb kockázatát, 2-es típusú diabetes fennállása esetén a depresszió mérsékelten emelkedett kockázatát (RR 1,15; 95\% CI 1,02-1,30) találták [24].

Egy nemrég megjelent metaanalízis szerint - a depresszió súlyosságát önértékelő kérdőívekkel és egy esetben a diagnosztikus kritériumok alapján megítélve - a depresszió előfordulása mérsékelten emelkedett praediabetesben (OR 1,11; 95\% CI 1,03-1,19), valamint olyan egyéneknél, akiknek még nem diagnosztizált cukorbetegségük van (OR 1,27; 95\% CI 1,02-1,59), és feltünően emelkedett a már diagnosztizált cukorbetegek körében (OR 1,80; 95\% CI 1,40-2,31) a normál szénhidrát-háztartású egyénekhez képest. Ez a dózis-hatás összefüggés felveti, hogy a komorbid cardiovascularis betegségek, illetve a diagnózis ténye, a kezelés bonyolultsága fontos befolyásoló tényezői lehetnek a depreszszió és a diabetes közti kapcsolatnak [25].

\section{A kétirányú kapcsolatot potenciálisan magyarázó patofiziológiai mechanizmusok}

A diabetes és a depresszió közti kétirányú összefüggés magyarázatára többféle elmélet is született. Elképzelhető, hogy a két betegség közös patogenetikai/etiológiai háttere magyarázza a kapcsolatot. Ebben az esetben nincs direkt összefüggés a két betegség között, megelőzésük a közös ok kezelésén alapulhat. Ugyanakkor felmerül az is, hogy a depresszió és a diabetes is direkt oki kapcsolatban áll a másik betegséggel, ami azt jelentené, hogy az egyik betegség kezelése a másik megelőzésében is hasznos lehet. Az sem kizárt azonban, hogy az obszer- 
vációs epidemiológiai vizsgálatokban gyakran megfigyelt különböző torzítások és nem valódi összefüggések állnak a háttérben [26].

\section{Közös etiológiai háttér}

A depresszió és a cukorbetegség között fennálló esetleges genetikai összefüggés vizsgálatát nehezíti, hogy mind a cukorbetegség, mind a depresszió multifaktoriális kórképek, melyek etiológiájában az egyes genetikai tényezők szerepe igen korlátozott. Nem meglepő tehát, hogy Scherrer és mtsai középkorú férfi ikrek körében nem találtak bizonyítékot arra, hogy az ikrek közös genetikai háttere fokozná a két betegség együttes előfordulásának kockázatát. Vizsgálatuk ugyanakkor megerősítette a két betegség együttes előfordulásával és az egyes betegségek jelentős genetikai (születést megelőző) meghatározottságával kapcsolatos megfigyeléseket [27].

Hasonló eredményre jutott egy másik ikervizsgálat is: a svéd ikerregiszter 40 év feletti egypetéjű és kétpetéjü ikrei körében $(n=37043)$ sem találtak fokozott genetikai kockázatot a két betegség egyidejû előfordulására, viszont az ikreket érő közös környezeti hatások állhatnak a kétirányú kapcsolat hátterében [28].

Egy harmadik vizsgálat összefüggést talált depresszióban szenvedő betegek agyspecifikus triptofán-hidroxiláz-2 (TPH2)-génje és a metabolikus szindróma kockázata között. Eredményeik alapján a TPH2 polimorfizmusa a depressziós betegek egy olyan alcsoportjára jellemző, amelynek tagjai különösen hajlamosak a metabolikus szindróma kialakulására [29].

Hazánkban Nagy Géza és mtsai a diabetes és a komorbid depresszió genetikai hátterét vizsgálták. Eredményeik alapján szignifikáns genetikai hatás mutatkozott a P2RX7 purinerg ioncsatornagén polimorfizmusa és a HADS (Hospital Anxiety and Depression Scale) kérdőívvel mért depresszív tünetek szintje között, illetve szignifikáns összefüggést találtak a TPH2-gén variánsai és a cukorbetegek depressziós tünetei között [30].

Mivel a depresszió és a diabetes is szoros összefüggést mutat életmódi és szocioekonomikus faktorokkal, feltételezhető, hogy együttes előfordulásukat közös környezeti tényezők magyaráznák. A társadalmi-gazdasági tényező́k közül az alacsony társadalmi helyzet a cukorbetegség és a depresszió kialakulásának kockázatát egyaránt növeli [31]. Freeman és mtsai Európa 3 országában (Finnország, Lengyelország, Spanyolország) végzett vizsgálatukban arra a következtetésre jutottak, hogy szignifikáns összefüggés van a depresszió és az alacsony társadalmi-gazdasági státusz között. Ennek hátterében elsősorban az iskolai végzettség állhat, míg a jövedelem mértéke nem volt független meghatározó [32].

Közös életmódi tényezők, amelyek növelhetik mindkét betegség kockázatát: a dohányzás, a fokozott alkoholfogyasztás, a mozgásszegény életmód és az egészségtelen táplálkozás [33, 34].
A depresszió etiológiájában jól ismert a stresszrendszer aktiválódásának és zavarának szerepe. A krónikus stressz aktiválja a hypothalamus-hypophysis-mellékvese tengelyt és a szimpatikus idegrendszert, aminek hatására emelkedik a kortizol, az adrenalin és a noradrenalin szintje [35]. Ez a krónikus hypercortisolismus és szimpatikus idegrendszeri aktiválódás inzulinrezisztenciához, visceralis obesitashoz, metabolikus szindrómához és 2-es típusú diabetes mellitushoz vezethet [36]. A hypothalamus-hypophysis-mellékvese tengely regulációs zavara megjelenhet a kortizolszintek napi ritmusának elvesztésében (lapos kortizolgörbe) is, ami mind a depressziós, mind a cukorbetegek között gyakoribb, és összefüggést mutat a cardiovascularis rizikóval, a diabetes kialakulásával és cukorbetegek között a rosszabb anyagcserehelyzettel [37].

Közös kóroki tényezőként az inzulinszerű növekedési faktor-I (IGFI) szerepe is felmerült, amelynek a normáltartománytól való eltérése depresszióhoz, inzulinrezisztenciához, idővel cukorbetegséghez vezethet $[38,39]$.

Mind depresszióban, mind diabetesben megfigyelhetó az immunrendszer múködési zavara és a gyulladásos citokinek termelódésének növekedése. Ezek a citokinek kölcsönhatásba lépnek a hasnyálmirigy béta-sejtjeivel és az adipocytákkal, így inzulinrezisztenciát és béta-sejtmúködési zavart okoznak, ami a 2-es típusú cukorbetegség kialakulásához vezet [40].

Egy nemrég megjelent metaanalízis (19 tanulmány, n = 39 136) megerősíti a 2 -es típusú cukorbetegség kialakulása és a gyulladásos citokinek közti kapcsolatra vonatkozó feltételezéseket. Eredményei szerint a C-reaktív protein (RR 1,48; 95\% CI 1,26-1,71) és az interleukin-6 szoros pozitív (RR 1,32; 95\% CI 1,14-1,51), míg az adiponektin negatív összefüggést mutatott a 2 -es típusú diabetes kialakulásával (RR 0,47; 95\% CI 0,32-0,61) [41]. Egy másik metaanalízis emelkedett TNF $\alpha$ - és interleukin-6-szinteket írt le depresszióban szenvedő betegekben [42]. A feltételezett összefüggést tovább támogatja az, hogy 2-es típusú cukorbetegek között a depresszív tünetek súlyossága dózis-hatás összefüggést mutatott a gyulladásos molekulák szintjével [43].

A fenti vizsgálatok alapján feltételezhetó, hogy a tartós stressz, a gyulladásos folyamatok és az inzulinszerú növekedési faktor-I fontos szerepet játszanak mind a depresszió, mind pedig a cukorbetegség kialakulásában.

\section{A depresszió, illetve kezelésének lehetséges hatása a cukorbetegség kialakulására és súlyosságára}

Az antidepresszív gyógyszereknek a cukorbetegség kialakulásában játszott szerepével összefüggésben számos vizsgálat született. Az antidepresszívumok javítják a betegek hangulatát, segíthetik a kezelésben való együttmúködésüket, egyes gyógyszerek pedig csökkenthetik a neuropathiás fájdalmat is. Összességében csökkenthetik a cukorbetegség kockázatát, javíthatják a kezelés sikeressé- 
gét. Ugyanakkor ezen gyógyszerek egy része nem anyagcsere-semleges. Különböző mellékhatásokon keresztül (testsúlynövekedés, hyper-, hypoglykaemiás hatás) ronthatják a szénhidrátháztartást, ezért cukorbetegek esetében fontos a metabolikus mellékhatások ismerete és figyelembevétele [44]. Saját populációs alapú vizsgálatunk eredményei szerint az antidepresszánsok kumulatív dózisa pozitív összefüggést mutatott a későbbi diabetes kockázatával és a súlynövekedés mértékével [45]. A szelektív szerotoninvisszavétel-gátlók kedvezőbbnek tûnnek cukorbetegekben a triciklusos és a noradrenerg antidepresszánsokkal szemben [46]. Az antidepresszívumok és a cukorbetegség közti kapcsolat vizsgálatát nehezíti, hogy a kezelési módot befolyásolja a depresszió súlyossága, az antidepresszívumkezelés hossza, az antidepresszívum dózisa, ami önmagában is a 2-es típusú cukorbetegség fokozott kockázatával jár [47].

A depresszió kezelésében a gyógyszeres terápia mellett fontos megemlíteni a pszichoterápia szerepét is. A kognitív viselkedésterápia a cukorbetegségről való oktatással kombinálva nemcsak a major depresszió hatékony kezelésére alkalmas, hanem a glykaemiás kontrollt is javíthatja [48]. Egy kis létszámú, randomizált, kontrollált vizsgálatban a kognitív viselkedésterápia hatását vizsgálták a depresszióra és a cukorbetegség kezelésével való együttmúködésre, unipoláris depressziós, nem megfelelően kontrollált 2-es típusú cukorbetegek körében. Minden beteg részletes felvilágosítást és képzést kapott a gyógyszereléssel, vércukor-önellenőrzéssel, táplálkozással és életmódi faktorokkal kapcsolatban. Az aktív ágra randomizált betegek ezenfelül kognitív viselkedésterápiában is részesültek. A 4, 8 és 12 hónapos kontrollokon az aktív ágon javult az adherencia (különbség: gyógyszerszedés - 16,3\%; 95\% CI 6,5-26,1\%; vércukor-önellenőrzés $22,3 \%$; 95\% CI 8,6-36,1\%;) és 0,63\%-kal (95\% CI 0,06$1,2 \%)$ alacsonyabb volt a $\mathrm{HbA}_{1 \mathrm{c}}$-érték. A depressziós tünetek mindkét csoportban hasonlóan javultak [49].

A depresszió súlyossága negatívan hat a diabeteses betegek antidiabetikus kezelési és diétás adherenciájára. Ugyanakkor romló fizikai és mentális státuszuk következtében magasabb az ellátás költsége is [50]. Depreszsziós betegek körében gyakrabban figyelhetők meg egészségre káros magatartásformák. A tartós vagy romló depressziós tünetekkel élő cukorbetegeknek rosszabb az együttmúködésük a diéta és a testmozgás terén a nem depressziós cukorbetegekhez képest [26].

\section{A diabetes potenciális hatása a depresszió kialakulására}

A cukorbetegség más krónikus, élethosszig tartó betegségekhez hasonlóan szorongást okozhat a betegekben. A kezelés bonyolultsága és a cukorbetegség szövődményeitől való félelem ronthatja a betegek életminőségét, hangulatát.
Meurs és mtsai közel 100000 embert követő vizsgálata alapján felvetődik, hogy döntően a diagnosztizált cukorbetegséggel járó betegségteher és pszichológiai hatások növelik a szorongásos zavarok kockázatát, míg a diabetesszel összefüggő patofiziológiai változások a depresszív zavarok kisfokú növekedésével járnak, bár a vizsgálat jellegéből adódóan ok-okozati összefüggéseket nem tudtak megállapítani [18]. Hasonló összefüggésre utal Kivimäki és mtsai elemzése is, ami egyértelmüen megerősíti, hogy a diagnosztizált cukorbetegek körében gyakoribb az antidepresszáns-használat, ugyanakkor a nem diagnosztizált cukorbetegek körében a háttér-populációnak megfelelő mértékű a gyógyszerhasználat. Ez a vizsgálat arra is felhívja a figyelmet, hogy a cukorbetegség diagnózisa miatti gyakoribb orvos-beteg találkozások következtében hamarabb és könnyebben kiderül a depresszió diagnózisa (szürési torzítás) [51].

A már kialakult szövődmények önmagukban is növelik a depresszió kockázatát, együttes előfordulásuk esetén pedig ez tovább növekszik [52].

A fájdalmas diabeteses neuropathia rontja a betegek életminőségét, zavarja alvásukat (mivel általában a panaszok nyugalomban és éjszaka jelentkeznek), és depressziós tünetegyüttes kialakulásához vezethet. Egy metaanalízis (13 tanulmány, $\mathrm{n}=3898$ ) szoros összefüggést talált a depresszió és a neuropathia jelenléte között (OR 2,01; 95\% CI 1,60-2,54) 2-es típusú cukorbetegekben. Bár az összefüggés iránya a vizsgálatok keresztmetszeti jellegéből adódóan nem értékelhető, feltételezhetően kétirányú kapcsolatról van szó: egyrészról a depresszióban és diabetesben is szenvedő betegek hajlamosabbak lehetnek neuropathia kialakulására, másrészről pedig a neuropathiában szenvedő cukorbetegek a krónikus tünetek miatt hajlamosabbak depresszió kialakulására [53].

Azoknál a cukorbetegeknél, akik depresszióban is szenvednek, gyakrabban alakulnak ki a cukorbetegség microvascularis (retinopathia, nephropathia, neuropathia és szexuális diszfunkció) és macrovascularis szövődményei [54]. Fontos hangsúlyoznunk, hogy a depresszió növeli a cukorbetegek morbiditását és mortalitását is [55].

A cukorbetegség központi idegrendszeri tünetekkel társulhat, hatására kognitív zavarok alakulhatnak ki. A diabetesszel összefüggésben az agyban strukturális változások is létrejöhetnek, a cukorbetegség jól ismert vascularis szövődménye a cerebralis atrophia és a lacunaris infarctusok kialakulása. A kognitív zavarok hátterében a hippocampusra lokalizálódó zavart feltételeznek, amelynek súlyossága a vércukorszint függvénye lehet. Inverz kapcsolatot találtak a glykaemiás kontroll $\left(\mathrm{HbA}_{\mathrm{lc}_{\mathrm{c}}}\right.$-szintek) és a hippocampus mérete között [56].

Hasonló következtetésekre jutott egy 2015-ben publikált metaanalízis is, amely az agy szerkezeti változásait vizsgálta 1-es és 2-es típusú diabetesesek körében. 1-es típusú diabetesben a thalamusok mérete csökkent volt a kontrollokéhoz képest, míg 2-es típusú cukorbetegek körében az agy össztérfogata, illetve egyes specifikus 
agyterületek (hippocampus, basalis ganglionok, orbitofrontalis és occipitalis területek) mérete volt kisebb. Az agyi össztérfogat-csökkenés hátterében elsősorban atheroscleroticus faktorok állhatnak (macro- és microvascularis betegség), a hippocampusatrophia pedig szerepet játszhat a cukorbetegség és a depresszió, illetve a dementia komorbid kialakulásában [57].

A cukorbetegséghez hasonlóan, depresszióban is megváltozik az agy szerkezete, csökken a hippocampus állománya. Ezt támasztja alá Cole és mtsai metaanalízise: vizsgálatukban rámutattak arra, hogy ez a változás nemcsak a hosszú ideje fennálló (rekurrens vagy krónikus) depresszióban figyelhető meg, hanem már a betegség első epizódjában is [58].

\section{Következtetések}

A diabetes és a depresszió közötti kapcsolat magyarázatára számos elmélet született, azonban ezen hipotézisek további megerősítést igényelnek. Mindettől függetlenül érdemes felhívni a szakemberek figyelmét a cukorbetegek kezelése során a pszichés állapot felmérésének fontosságára, illetve a depressziós betegcsoport kezelése kapcsán a cukorbetegség irányába történő szürésre. A korai felismerés és kezelés javítja a betegek együttmúködését, csökkentve a két betegség komorbiditásából adódó komplikációkat.

Az alapellátás szerepe a magas orvos-beteg találkozási szám és a könnyű elérhetőség miatt kiemelkedő mindkét betegség szűrésében és a korai ellátásban. A családorvosok pácienseiket a rövidített Beck Depresszió Kérdőívvel és a Reménytelenség Skálával szürhetik depresszió és az öngyilkossági veszély irányába [59]. A cukorbetegség korai felismerését segíti a FINDRISC-kérdőív használata, valamint laboratóriumi vizsgálatok elvégzése: az éhomi vércukorszint ellenőrzése, OGTT-vizsgálat vagy $\mathrm{HbA}_{1 \mathrm{c}}$-meghatározás [60-62].

A törzskarton használatával a jövőben lehetőség nyílik három év alatt a teljes praxis szűrésére, melynek része a depresszív tünetek felmérése is. Így javulhat a depresszió felismerési aránya a cukorbetegek között, ami az időben elkezdett antidepresszív kezelés eredményeként sikeresebb antidiabetikus kezeléshez, jobb terápiás együttmüködéshez és kedvezőbb hosszú távú életminőséghez vezethet.

Anyagi támogatás: A tanulmány elkészítése anyagi támogatásban nem részesült.

Szerzői munkamegosztás: A szerzők egyenlő arányban vettek részt a közlemény megírásában. A cikk végleges változatát valamennyi szerző elolvasta és jóváhagyta.

Érdekeltségek: A szerzőknek nincsenek érdekeltségeik.

\section{Irodalom}

[1] International Diabetes Federation. IDF Diabetes Atlas. Eight edition, 2017. Available from: http://www.diabetesatlas.org [accessed: December 10, 2018].

[2] Jermendy G, Nádas J, Szigethy E, et al. Prevalence rate of diabe tes mellitus and impaired fasting glycemia in Hungary: crosssectional study on nationally representative sample of people aged 20-69 years. Croat Med J. 2010; 51: 151-156.

[3] Kempler P, Putz Zs, Kiss Z, et al. Prevalence and financial burden of type 2 diabetes mellitus in Hungary between 2001-2014 results of the analysis of the National Health Insurance Fund database. [A 2-es típusú diabetes előfordulása és költségterheinek alakulása Magyarországon 2001-2014 között - az Országos Egészségbiztosítási Pénztár adatbázis-elemzésének eredményei.] Diab Hung. 2016; 24: 177-188. [Hungarian]

[4] World Health Organization. Diabetes country profiles 2016. Hungary. WHO, Geneva. Available from: https://www.who. int/diabetes/country-profiles/hun_en.pdf?ua $=1$ [accessed: December 10, 2018].

[5] Vámos EP, Kopp MS, Keszei A, et al. Prevalence of diabetes in a large, nationally representative population sample in Hungary. Diabetes Res Clin Pract. 2008; 81: e5-E8.

[6] Domján BA, Ferencz V, Tänczer T, et al. Large increase in the prevalence of self-reported diabetes based on a nationally representative survey in Hungary. Prim Care Diabetes 2017; 11: 107111.

[7] World Health Organization. Depression and other common mental disorders. Global Health Estimates. WHO, Geneva, 2017. Available from: http://www.who.int/mental_health/ management/depression/prevalence_global_health_estimates/ en/ [accessed: December 10, 2018].

[8] World Federation for Mental Health. DEPRESSION: A global crisis. World Mental Health Day, October 10 2012. WHO, Geneva. Available from: http://www.who.int/mental_health/ management/depression/wfmh_paper_depression_wmhd_ 2012.pdf [accessed: December 10, 2018].

[9] Szádóczky E, Rihmer Z, Papp Z, et al. The prevalence of affective and anxiety disorders in primary care practice in Hungary. $J$ Affect Disord. 1997; 43: 239-244

[10] Rihmer Z, Gonda X, Eőry A, et al. Screening of depression in primary care in Hungary and its importance in suicide prevention. [A depresszió szűrése az alapellátásban Magyarországon és ennek jelentősége az öngyilkosság megelőzésében.] Psychiatr Hung. 2012; 27: 224-232. [Hungarian]

[11] Torzsa P, Rihmer Z, Gonda X, et al. Family history of suicide: a clinical marker for major depression in primary care practice? $\mathrm{J}$ Affect Disord. 2009; 117: 202-204.

[12] Siu AL, US Preventive Services Task Force (USPSTF). Screening for depression in adults: US Preventive Services Task Force Recommendation Statement. JAMA 2016; 315: 380-387.

[13] O'Connor E, Rossom RC, Henninger M, et al. Primary care screening for and treatment of depression in pregnant and postpartum women: evidence report and systematic review for the US Preventive Services Task Force. JAMA 2016; 315: 388-406.

[14] Rihmer Z, Rutz W. Treatment of attempted suicide and suicidal patients in primary care. In: Wasserman D, Wasserman C. (eds.) Oxford Textbook of Suicidology and Suicide Prevention. Oxford University Press, Oxford, 2009; pp. 463-470.

[15] Eurostat Statistics Explained. Causes of death - standardised death rate, 2015 (per 100000 inhabitants) HLTH18.png. Eurostat, Luxembourg. Available from: https://ec.europa.eu/eurostat/statistics-explained/index.php?title=File:Causes_of_ death_\%E2\%80\%94_standardised_death_rate,_2015_(per_100_ 000_inhabitants)_HLTH18.png [accessed: December 10, 2018]. 
[16] Torzsa P, Szeiffert L, Dunai K, et al. Diagnosis and therapy of depression in primary care. [A depresszió diagnosztikája és kezelése a családorvosi gyakorlatban.] Orv Hetil. 2009; 150: 1684-1693. [Hungarian]

[17] Willis T. Diabetes: a medical Odyssey. USV Pharmaceutical Corp., Tuckahoe, NY, 1971.

[18] Meurs M, Roest AM, Wolffenbuttel BH, et al. Association of depressive and anxiety disorders with diagnosed persus undiagnosed diabetes: An epidemiological study of 90,686 participants. Psychosom Med. 2016; 78: 233-241.

[19] Anderson RJ, Freedland KE, Clouse RE, et al. The prevalence of comorbid depression in adults with diabetes: a meta-analysis. Diabetes Care 2001; 24: 1069-1078.

[20] Ali S, Stone MA, Peters JL, et al. The prevalence of co-morbid depression in adults with type 2 diabetes: a systematic review and meta-analysis. Diabet Med. 2006; 23: 1165-1173.

[21] Kivimäki M, Tabák AG, Lawlor DB, et al. Antidepressant use before and after the diagnosis of type 2 diabetes: a longitudinal modeling study. Diabetes Care 2010; 33: 1471-1476.

[22] Rotella F, Mannucci E. Diabetes mellitus as a risk factor for depression. A meta-analysis of longitudinal studies. Diabetes Res Clin Pract. 2013; 99: 98-104.

[23] Eaton WW, Armenian H, Gallo J, et al. Depression and risk for onset of type II diabetes. A prospective population-based study Diabetes Care 1996; 19: 1097-1102.

[24] Mezuk B, Eaton WW, Albrecht S, et al. Depression and type 2 diabetes over the lifespan: a meta-analysis. Diabetes Care 2008; 31: 2383-2390

[25] Chen S, Zhang Q, Dai G, et al. Association of depression with pre-diabetes, undiagnosed diabetes, and previously diagnosed diabetes: a meta-analysis. Endocrine 2016; 53: 35-46.

[26] Tabák AG, Akbaraly TN, Batty GD, et al. Depression and type 2 diabetes: a causal association? Lancet Diabetes Endocrinol. 2014; 2 : 236-245.

[27] Scherrer JF, Xian H, Lustman PJ, et al. A test for common genetic and environmental vulnerability to depression and diabetes. Twin Res Hum Genet. 2011; 14: 169-172.

[28] Mezuk B, Heh V, Prom-Wormley E, et al. Association between major depression and type 2 diabetes in midlife: findings from the Screening Across the Lifespan Twin Study. Psychosom Med. 2015; 77: 559-566

[29] Kloiber S, Kohli MA, Brueckl T, et al. Variations in tryptophan hydroxylase 2 linked to decreased serotonergic activity are associated with elevated risk for metabolic syndrome in depression. Mol Psychiatry 2010; 15: 736-747.

[30] Nagy G, Ronai Z, Somogyi A, et al. P2RX7 Gln460Arg polymorphism is associated with depression among diabetic patients. Prog Neuropsychopharmacol Biol Psychiatry 2008; 32: 1884 1888 .

[31] Agardh E, Allebeck P, Hallqvist J, et al. Type 2 diabetes incidence and socio-economic position: a systematic review and meta-analysis. Int J Epidemiol. 2011; 40: 804-818.

[32] Freeman A, Tyrovolas S, Koyanagi A, et al. The role of socioeconomic status in depression: results from the COURAGE (aging survey in Europe). BMC Public Health 2016; 16: 1098.

[33] Berk M, Sarris J, Coulson CE, et al. Lifestyle management of unipolar depression. Acta Psychiatr Scand. 2013; 127(Suppl 443): $38-54$.

[34] van Dam RM. The epidemiology of lifestyle and risk for type 2 diabetes. Eur J Epidemiol. 2003; 18: 1115-1125.

[35] Plotsky PM, Owens MJ, Nemeroff CB. Psychoneuroendocrinology of depression. Hypothalamic-pituitary-adrenal axis. Psychiatr Clin North Am. 1998; 21: 293-307.

[36] Chrousos GP. The role of stress and the hypothalamic-pituitaryadrenal axis in the pathogenesis of the metabolic syndrome: neuro-endocrine and target tissue-related causes. Int J Obes Relat Metab Disord. 2000; 24(Suppl 2): S50-S55.
[37] Joseph JJ, Golden SH. Cortisol dysregulation: the bidirectional link between stress, depression, and type 2 diabetes mellitus. Ann N Y Acad Sci. 2017; 1391: 20-34.

[38] Kopczak A, Stalla GK, Uhr M. IGF-I in major depression and antidepressant treatment response. Eur Neuropsychopharmacol. $2015 ; 25: 864-872$.

[39] Friedrich N, Thuesen B, Jørgensen T, et al. The association between IGF-I and insulin resistance: a general population study in Danish adults. Diabetes Care 2012; 35: 768-773.

[40] Pickup JC, Crook MA. Is type II diabetes mellitus a disease of the innate immune system? Diabetologia 1998; 41: 1241-1248.

[41] Liu C, Feng X, Li Q, et al. Adiponectin, TNF- $\alpha$ and inflammatory cytokines and risk of type 2 diabetes: a systematic review and meta-analysis. Cytokine 2016; 86: 100-109.

[42] Dowlati Y, Herrmann N, Swardfager W, et al. A meta-analysis of cytokines in major depression. Biol Psychiatry 2010; 67: 446457.

[43] Laake JP, Stahl D, Amiel SA, et al. The association between depressive symptoms and systemic inflammation in people with type 2 diabetes: findings from the South London Diabetes Study. Diabetes Care 2014; 37: 2186-2192.

[44] Fava M. Weight gain and antidepressants. J Clin Psychiatry 2000; 61(Suppl 11): 37-41.

[45] Kivimäki M, Hamer M, Batty GD, et al. Antidepressant medication use, weight gain, and risk of type 2 diabetes: a populationbased study. Diabetes Care 2010; 33: 2611-2616.

[46] Deuschle M. Effects of antidepressants on glucose metabolism and diabetes mellitus type 2 in adults. Curr Opin Psychiatry 2013; 26: 60-65.

[47] Andersohn F, Schade R, Suissa S, et al. Long-term use of antidepressants for depressive disorders and the risk of diabetes mellitus. Am J Psychiatry 2009; 166: 591-598.

[48] Lustman PJ, Griffith LS, Freedland KE, et al. Cognitive behavior therapy for depression in type 2 diabetes mellitus. A randomized, controlled trial. Ann Intern Med. 1998; 129: 613-621.

[49] Safren SA, Gonzalez JS, Wexler DJ, et al. A randomized controlled trial of cognitive behavioral therapy for adherence and depression (CBT-AD) in patients with uncontrolled type 2 diabetes. Diabetes Care 2014; 37: 625-633. Erratum Diabetes Care 2016; 39: 1065.

[50] Ciechanowski PS, Katon WJ, Russo JE. Depression and diabetes: impact of depressive symptoms on adherence, function, and costs. Arch Intern Med. 2000; 160: 3278-3285.

[51] Kivimäki M, Batty GD, Jokela M, et al. Antidepressant medication use and risk of hyperglycemia and diabetes mellitus: a noncausal association? Biol Psychiatry 2011; 70: 978-984.

[52] Deschênes SS, Burns RJ, Pouwer F, et al. Diabetes complications and depressive symptoms: prospective results from the Montreal Diabetes Health and Well-Being Study. Psychosom Med. 2017; 79: 603-612.

[53] Bartoli F, Carrà G, Crocamo C, et al. Association between depression and neuropathy in people with type 2 diabetes: a metaanalysis. Int J Geriatr Psychiatry 2016; 31: 829-836.

[54] Lin EH, Rutter CM, Katon W, et al. Depression and advanced complications of diabetes: a prospective cohort study. Diabetes Care 2010; 33: 264-269.

[55] Park M, Katon WJ, Wolf FM. Depression and risk of mortality in individuals with diabetes: a meta-analysis and systematic review. Gen Hosp Psychiatry 2013; 35: 217-225.

[56] Gold SM, Dziobek I, Sweat V, et al. Hippocampal damage and memory impairments as possible early brain complications of type 2 diabetes. Diabetologia 2007; 50: 711-719.

[57] Moulton CD, Costafreda SG, Horton P, et al. Meta-analyses of structural regional cerebral effects in type 1 and type 2 diabetes. Brain Imaging Behav. 2015; 9: 651-662.

[58] Cole J, Costafreda SG, McGuffin P, et al. Hippocampal atrophy in first episode depression: a meta-analysis of magnetic resonance imaging studies. J Affect Disord. 2011; 134: 483-487. 
[59] Rihmer Z, Blazsek P, Hargittay Cs, et al. Depression, anxiety and suicidal behavior. Recognition and care. [Depresszió, szorongás és az öngyilkos magatartás. Felismerés és ellátás.] Lege Artis Med. 2018; 28: 287-292. [Hungarian]

[60] Tabák AG, Herder C, Rathmann W, et al. Prediabetes: a highrisk state for diabetes development. Lancet 2012; 379: 22792290.

[61] Herder C, Kowall B, Tabák AG, et al. The potential of novel biomarkers to improve risk prediction of type 2 diabetes. Diabetologia $2014 ; 57$ : 16-29.
[62] Torzsa P, Oláh I, Hargittay Cs, et al. Type 2 diabetes: what is the role of a general practitioner in the treatment of diabetes? [2-es típusú cukorbetegség: milyen szerepe van a családorvosnak a betegség kezelésében?] Lege Artis Med. 2018; 28: 533-540. [Hungarian]

(Hargittay Csenge dr., Budapest, Pf. 2, 1428 e-mail: hargittay.csenge@gmail.com)

\section{„Audiatur et altera pars." (Seneca) (A másik felet is meg kell hallgatni.)}

A cikk a Creative Commons Attribution 4.0 International License (https://creativecommons.org/licenses/by/4.0/) feltételei szerint publikált Open Access közlemény, melynek szellemében a cikk bármilyen médiumban szabadon felhasználható, megosztható és újraközölhető, feltéve, hogy az eredeti szerző és a közlés helye, illetve a CC License linkje és az esetlegesen végrehajtott módosítások feltüntetésre kerülnek. (SID_1) 